\title{
Trial of canakinumab, an IL- $1 \beta$ receptor antagonist, in patients with inclusion body myositis
}

Michalis L. Kosmidis, MD, Dimitris Pikazis, MD, Panayotis Vlachoyiannopoulos, MD, Athanasios G. Tzioufas, MD, and Marinos C. Dalakas, MD, FAAN

Neurol Neuroimmunol Neuroinflamm 2019;6:e581. doi:10.1212/NXI.0000000000000581

\section{Abstract}

\section{Objective}

To assess whether canakinumab, a monoclonal antibody against IL- $1 \beta$ approved for autoinflammatory diseases, is effective as target-specific therapy in patients with sporadic inclusion body myositis (sIBM).

\section{Methods}

Because in sIBM IL-1 $\beta$ colocalizes with amyloid precursor protein and upregulates amyloid aggregates enhancing degeneration, targeting IL- $1 \beta$ with canakinumab may arrest disease progression. On this basis, 5 ambulatory patients with sIBM participated in an institutional review board-approved open-labeled study with $150 \mathrm{mg}$ canakinumab [4 bimonthly, then monthly subcutaneous injections] for a mean period of 15.8 months. Patients were assessed bimonthly with a manual dynamometer in 12 proximal and distal muscles and with grip force (GF) in both hands. Total muscle strength (TMS) was expressed in kilograms. Efficacy was defined as $>15 \%$ increased strength after 12 months.

\section{Results}

Patient 1 stopped at month 5 because of $23 \%$ loss in TMS and $32.35 \%$ in GF; patient 2 showed $37.1 \%$ increase in TMS and 13\% in GF by month 9; patient 3 exhibited $26.7 \%$ reduction in TMS and $10 \%$ in GF at month 33; patient 4 showed $6.5 \%$ reduction in TMS and $1.6 \%$ in GF after 15 months, denoting relative stability; and patient 5 showed $30.4 \%$ loss in TMS and $20.8 \%$ in GF after 18 months. In patients 2 and 4, in whom 3-year longitudinal data were available, no effect on disease progression was noted.

\section{Conclusions}

In this long-term, open-label study, canakinumab showed small, but not clinically appreciable, stabilizing benefits in 2 of 5 patients with sIBM over 1 year, was ineffective in 2 others, and might have worsened one. No patient improved.

\section{Classification of evidence}

This study provides Class IV evidence that canakinumab was ineffective for patients with sIBM.
Correspondence

Dr. Dalakas

mdalakas@med.uoa.gr

\section{MORE ONLINE}

$\rightarrow$ Class of Evidence

Criteria for rating

therapeutic and diagnostic

studies

NPub.org/coe 


\section{Glossary}

GF = grip force; $\mathbf{s I B M}=$ sporadic inclusion body myositis; $\mathbf{T M S}=$ total muscle strength .

Sporadic inclusion body myositis (sIBM) is the most common inflammatory myopathy above age 50 years with early involvement of quadriceps femoris, long finger flexors, biceps, foot dorsiflexors, and mild facial weakness. ${ }^{1}$ IBM is slowly progressive, over years, with an estimated mean annual decline in strength by $5.4 \%$ based on quantitative muscle strength testing ${ }^{2}$ or by a 3.87 modified medical research council score per year. ${ }^{3}$ The cause is unclear, but both inflammatory/autoimmune and degenerative changes coexist and may enhance each other. ${ }^{1}$ The autoimmune component is mainly characterized by activated and clonally expanded $\mathrm{CD}^{+}$cytotoxic $\mathrm{T}$ cells invading healthy-appearing and major histocompatibility complex-I-expressing muscle fibers, overexpression of costimulatory and adhesion molecules, upregulation of chemokines and cytokines, such as interleukin (IL)-1 $\alpha, \mathrm{IL}-1 \beta$, IL-2, tumor necrosis factor alpha and transforming growth factor, and activation of dendritic cells and B cells. ${ }^{1,4-9} \mathrm{IL}-1 \beta$, a potent proinflammatory cytokine secreted by monocytes and macrophages, seems to be in the interface between inflammation and degeneration because it colocalizes with amyloid precursor protein on muscle fibers and leads to overexpression of amyloid precursor protein with subsequent accumulation of $\beta$-amyloid, upregulation of inducible nitric oxide synthase, production of nitric oxide, and cell death of human myotubes exposed to IL- $1 \beta .{ }^{1,7-9}$ On this basis, we hypothesized that targeting IL- $1 \beta$ may arrest disease progression. Toward this goal, we first conducted a pilot study with anakinra, a nonselective IL1-receptor antagonist that blocks the biologic activity of IL-1, in 5 patients with sIBM. ${ }^{10}$ Anakinra, approved for rheumatoid arthritis, was ineffective in sIBM. ${ }^{10}$ We have now tested the efficacy of canakinumab, an IgGk monoclonal antibody, that offers a target-specific blockade of IL-1 $\beta$, as a more promising approach.

\section{Study design and patients}

\section{Canakinumab (Ilaris)}

Canakinumab binds with high affinity and specificity to human IL-1 $\beta$, blocking its interaction with IL-1 receptors. In this proof-of-principle, open-label study, we treated 5 patients with sIBM with $150 \mathrm{mg}$ subcutaneous canakinumab every 8 weeks, following the doses and schedules approved for the other autoinflammatory conditions, for a mean period of 15.8 months (range 5-33 months). In 3 patients ( 3 , 4, and 5), the schedule was empirically increased to monthly injections hoping for a better effect.

\section{Patients}

All patients were ambulatory at study entry and fulfilled the typical clinical and histologic criteria of sIBM. ${ }^{1,5}$ Two of 5 patients had also participated in our previous negative study with anakinra, and their available quantitative muscle strength data were used to assess whether canakinumab had any effect on disease progression. The patients' clinical characteristics are shown in the table.

Muscle strength, expressed in kilograms, was measured with a muscle dynamometer by the same examiner (M.L.K.) every 1 or 2 months assessing (1) the mean values of bilateral grip force (GF) and (2) total muscle strength (TMS) based on the sum score in 6 muscle groups bilaterally (12 groups total): arm abduction, elbow flexion, wrist extension, hip flexion, knee extension, and ankle dorsiflexion. All biopsies were performed and read by us (Prof. Dalakas's laboratory).

\section{Primary research question}

Class IV was defined as $>15 \%$ increased strength after 12 months.

\section{Standard protocol approvals, registrations, and patient consents}

All participants signed informed consent before the diagnostic muscle biopsy was performed and before entering the study. The study protocol was approved by the Institutional Review Board of the Laikon Hospital, Athens University Medical School. The study was registered at EudraCT (number: 2014004602-15).

\section{Data availability}

Anonymized data will be shared by request from any qualified investigator.

\section{Results}

\section{Treatment effect}

\section{Patient 1}

A 54-year-old man had progressive muscle weakness and atrophy for the last 12 years initially treated as polymyositis. The diagnosis of IBM was confirmed with a muscle biopsy performed 2 years before enrollment. Because of rapid progression, he was treated with intravenous immunoglobulin, methotrexate, and mycophenolate without improvement. He received canakinumab for 5 months, from November 2014 to April 2015. A 23\% loss in TMS and 32.35\% in GF was noted over a 5-month period (figure). He continued to worsen with more generalized weakness including facial muscles and dysphagia. The accelerated worsening, perceived as possibly related to the study drug, prompted early treatment discontinuation.

\section{Patient 2}

A 45-year-old woman had slowly progressive proximal and distal muscle weakness and typical clinicohistological features 
Table Main clinical characteristic of patients with sIBM participating in the canakinumab study

\begin{tabular}{|c|c|c|c|c|c|c|c|}
\hline & $\begin{array}{l}\text { Age at } \\
\text { symptom } \\
\text { onset }\end{array}$ & $\begin{array}{l}\text { Disease } \\
\text { duration }(y) \text { till } \\
\text { study } \\
\text { participation }\end{array}$ & Initial symptoms & $\begin{array}{l}\text { Muscle groups involved } \\
\text { during the course of the } \\
\text { disease and study } \\
\text { participation }\end{array}$ & Dysphagia & $\begin{array}{l}\text { Muscle } \\
\text { biopsy } \\
\text { findings }\end{array}$ & $\begin{array}{l}\text { Previous } \\
\text { therapies }\end{array}$ \\
\hline $\begin{array}{l}\text { Patient } \\
1\end{array}$ & 42 & 12 & $\begin{array}{l}\text { Lower extremity } \\
\text { weakness, followed } \\
\text { by upper extremities }\end{array}$ & $\begin{array}{l}\text { Facial and bulbar muscles; } \\
\text { upper and lower extremity } \\
\text { proximal and distal muscles }\end{array}$ & Yes & $\begin{array}{l}\text { Typical } \\
\text { for IBM }\end{array}$ & $\begin{array}{l}\text { IVIg, } \\
\text { methotrexate, } \\
\text { and } \\
\text { myocophenolate }\end{array}$ \\
\hline $\begin{array}{l}\text { Patient } \\
2\end{array}$ & 36 & 10 & $\begin{array}{l}\text { Upper and lower } \\
\text { proximal and distal } \\
\text { muscles }\end{array}$ & $\begin{array}{l}\text { Upper and lower proximal and } \\
\text { distal muscles }\end{array}$ & No & $\begin{array}{l}\text { Typical } \\
\text { for IBM }\end{array}$ & Anakinra \\
\hline $\begin{array}{l}\text { Patient } \\
3\end{array}$ & 51 & 29 & $\begin{array}{l}\text { Upper and lower } \\
\text { proximal and distal } \\
\text { muscles }\end{array}$ & $\begin{array}{l}\text { Upper and lower proximal and } \\
\text { distal muscles }\end{array}$ & No & $\begin{array}{l}\text { Typical } \\
\text { for IBM }\end{array}$ & $\begin{array}{l}\text { Mycophenolate } \\
\text { and steroids }\end{array}$ \\
\hline $\begin{array}{l}\text { Patient } \\
4\end{array}$ & 54 & 14 & $\begin{array}{l}\text { Upper and lower } \\
\text { proximal and distal } \\
\text { muscles }\end{array}$ & $\begin{array}{l}\text { Upper and lower proximal and } \\
\text { distal muscles }\end{array}$ & No & $\begin{array}{l}\text { Typical } \\
\text { for IBM }\end{array}$ & $\begin{array}{l}\text { Mycophenolate, } \\
\text { prednisolone, } \\
\text { and anakinra }\end{array}$ \\
\hline $\begin{array}{l}\text { Patient } \\
5\end{array}$ & 65 & 5 & $\begin{array}{l}\text { Upper and lower } \\
\text { proximal and distal } \\
\text { muscles }\end{array}$ & $\begin{array}{l}\text { Upper and lower proximal and } \\
\text { distal muscles }\end{array}$ & Yes & $\begin{array}{l}\text { Typical } \\
\text { for IBM }\end{array}$ & $\begin{array}{l}\text { No previous } \\
\text { treatments }\end{array}$ \\
\hline
\end{tabular}

Abbreviations: IBM = inclusion body myositis; IVIg = intravenous immunoglobulin; sIBM = sporadic inclusion body myositis.

Clinical characteristics of patients with sIBM participated in the canakinumab study. Two of five patients developed overt dysphagia during the disease course. Patients 2 and 4 had also participated in the previous study with anakinra. ${ }^{10}$

None of the patients was receiving any other immunotherapy during the study period with canakinumab.

of sIBM. She had participated in the anakinra study from 2010 to 2011 without benefit but steady progression. She received canakinumab from March 2016 to November 2016. A 37.1\% increase in TMS and $13 \%$ increase in GF were noted over an 8 -month treatment (figure). Of interest, when she received anakinra, she exhibited a $7.4 \%$ increase in TMS and a $30 \%$ decrease in $\mathrm{GF}^{10}$ suggesting a more beneficial effect of canakinumab in disease progression. Despite these mild gains however demonstrable in our measurements, the patient did not appreciate any positive functional changes in her daily activities and requested not to continue with additional treatments.

\section{Patient 3}

An 80-year-old woman had progressive muscle weakness for the last 29 years with typical clinicohistologic features of sIBM. She had received mycophenolate and steroids without benefit. At study entry, she was ambulatory with aids. She was treated with canakinumab for 33 months, from September 2015 until June 2018. A 26.7\% loss in TMS and $10 \%$ loss in GF were noted during the study period (figure). She reported progressive weakness with more difficulty in her daily activities and felt that the drug was ineffective.

Figure (A and B) Effect of canakinumab in muscle strength measured in each patient as mean bilateral GF (A) and TMS (B) during the mean study period of 15.8 months (range 5-33 months)
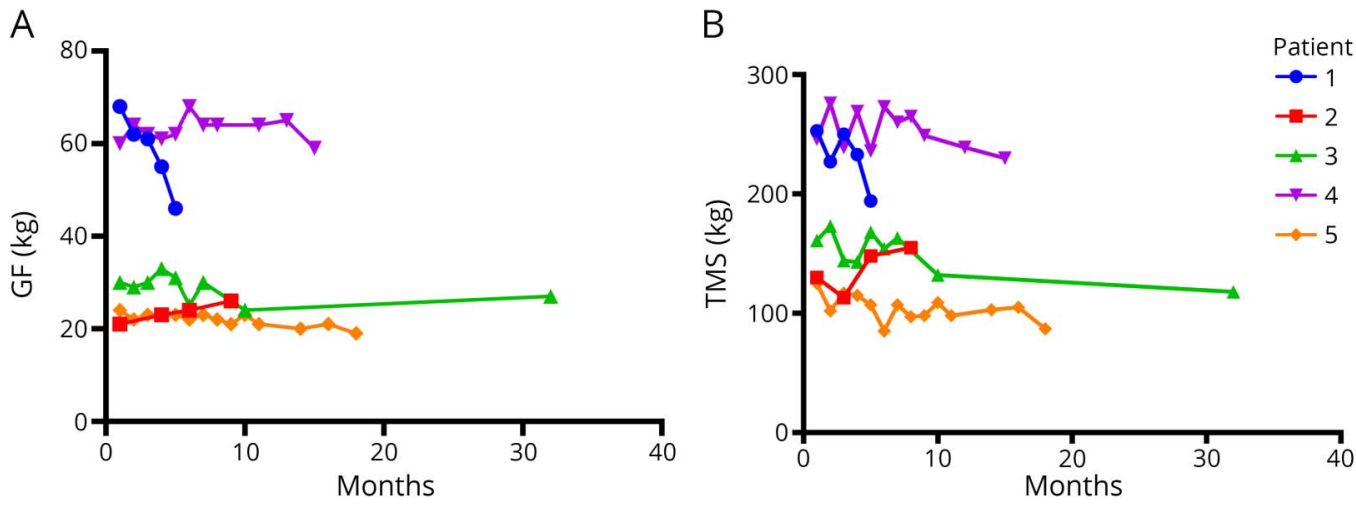

No significant or clinically meaningful changes were noted in improving strength or stabilizing disease progression. GF = grip force; TMS = total muscle strength. 


\section{Patient 4}

A 68-year-old man had progressive weakness for the last 14 years and typical sIBM. Treatment with mycophenolate and prednisolone was ineffective. He received canakinumab for 15 months, from April 2014 until July 2015. A 6.5\% reduction in TMS with $1.6 \%$ reduction in GF were noted during the study period, a sign we interpreted as disease stability (figure). He also reported functional improvement in the use of his hands after the first few months, but this benefit did not persist or captured in follow-up visits. The patient had participated in the anakinra study, from January 2010 until October 2010, and exhibited a 3.5\% reduction in TMS and 5\% reduction in GF.

\section{Patient 5}

A 70-year-old man had a 5-year history of progressive weakness and typical clinicohistologic features of sIBM. He received canakinumab for 18 months, from May 2015 to November 2016. Three months after therapy initiation, he underwent cholecystectomy for cholelithiasis. Following the operation, he reported worsening of his weakness and progressive dysphagia. A reduction in his muscle strength, by $30.4 \%$ in TMS and $20.8 \%$ in GF, was observed during the 18 month treatment period (figure).

\section{Discussion}

Canakinumab was well tolerated but had a variable effect in the 5 treated patients with sIBM. None of the patients improved. Two patients showed objective signs of disease stability, which were not however perceived by them as positively affecting their daily activities; 2 others continued to progress with the same pace as before therapy, even during a 33-month extended study period; and still another with accelerated disease progression might have worsened.

The ineffectiveness of the drug may be due to various reasons: (1) the patient's advanced disease at study entry that might have precluded clinically perceptive changes; (2) IL-1 $\beta$ blockade may not be meaningful after the disease is already advanced, although in vitro has a myotoxic effect and enhances amyloid accumulation; (3) the dose used might be insufficient to inhibit the inflammatory and neurodegenerative effect of IL-1 $\beta$; or (4) IL-1 $\beta$ might not be one of the primary players that drives progression and neuroinflammation in sIBM.

Whether canakinumab will have an effect in disease progression in a subset of patients with sIBM with early disease remains uncertain. Such a consideration is entertained because of the relative stability noted in 2 patients; this effect was, however, minor, and the rationale to conduct a future control trial in more patients with early disease using such an expensive drug may not be warranted.

\section{Study funding}

No targeted funding reported.

\section{Disclosure}

M.L. Kosmidis, D. Pikazis, P. Vlachoyiannopoulos, and A.G. Tzioufas report no disclosures. M.C. Dalakas served on the CIDP steering committee of Novartis and currently serves on DSMB for Baxalta and Octapharma; received travel funding and/or speaker honoraria from Baxter, CSL, and Merck/ Serono; serves on the editorial board of Neurology ${ }^{\circledR}$, Acta Myologica, Acta Neurologica Scandinavica, and Annals of Neurology and as associate editor of Therapeutic Advances in Neurology; consulted for Therapath, Novartis, Baxter, Octapharma, CSL, Pfizer AG, Dysimmune Diseases Foundation, and Elsevier; and received institutional support to Thomas Jefferson University and/or University of Athens Medical School from Merck Serono, Genzyme, Novartis, GuillainBarre/CIDP Foundation, Dysimmune Diseases Foundation, Biogen, and Newfactor. Go to Neurology.org/NN for full disclosures.

\section{Publication history}

Received by Neurology: Neuroimmunology \& Neuroinflammation February 12, 2019. Accepted in final form April 24, 2019.

\begin{tabular}{|c|c|c|c|}
\hline Name & Location & Role & Contributions \\
\hline $\begin{array}{l}\text { Kosmidis Michalis, } \\
\text { MD, PhD }\end{array}$ & $\begin{array}{l}\text { Athens } \\
\text { Medical } \\
\text { School }\end{array}$ & Author & $\begin{array}{l}\text { Analyzed the data, } \\
\text { drafted the manuscript } \\
\text { for intellectual content, } \\
\text { and major role in the } \\
\text { acquisition of data }\end{array}$ \\
\hline $\begin{array}{l}\text { Pikazis Dimitrios, } \\
\text { MD }\end{array}$ & $\begin{array}{l}\text { Athens } \\
\text { Medical } \\
\text { School }\end{array}$ & Author & $\begin{array}{l}\text { Major role in the } \\
\text { acquisition of data and } \\
\text { revised the manuscript } \\
\text { for intellectual content }\end{array}$ \\
\hline $\begin{array}{l}\text { Vlachoyiannopoulos } \\
\text { Panayiotis, MD }\end{array}$ & $\begin{array}{l}\text { Athens } \\
\text { Medical } \\
\text { School }\end{array}$ & Author & $\begin{array}{l}\text { Revised the manuscript } \\
\text { for intellectual content }\end{array}$ \\
\hline $\begin{array}{l}\text { Tzioufas Athanasios, } \\
\text { MD, PhD }\end{array}$ & $\begin{array}{l}\text { Athens } \\
\text { Medical } \\
\text { School }\end{array}$ & Author & $\begin{array}{l}\text { Revised the manuscript } \\
\text { for intellectual content }\end{array}$ \\
\hline $\begin{array}{l}\text { Dalakas Marinos, } \\
\text { MD, FAAN }\end{array}$ & $\begin{array}{l}\text { Athens } \\
\text { Medical } \\
\text { School }\end{array}$ & Author & $\begin{array}{l}\text { Designed and } \\
\text { conceptualized the } \\
\text { study, interpreted the } \\
\text { data, and revised } \\
\text { the manuscript for } \\
\text { intellectual content }\end{array}$ \\
\hline
\end{tabular}

\section{References}

1. Dalakas MC. Inflammatory muscle diseases. N Engl J Med 2015;372:1734-1747.

2. Cox FM, Titulaer MJ, Sont JK, Wintzen AR, Verschuuren JJ, Badrising UA. A 12-year follow-up in sporadic inclusion body myositis: an end stage with major disabilities. Brain 2011;134:3167-3175.

3. Peng A, Koffman BM, Malley JD, Dalakas MC. Disease progression in sporadic inclusion body myositis: observations in 78 patients. Neurology 2000;55:296-298.

4. Dalakas MC. Polymyositis, dermatomyositis and inclusion-body myositis. N Engl J Med 1991;325:1487-1498.

5. Dalakas MC. Sporadic inclusion body myositis-diagnosis, pathogenesis and therapeutic strategies. Nat Clin Pract Neurol 2006;2:437-447.

6. Keller CW, Schmidt J, Lunemann JD. Immune and myodegenerative pathomechanisms in inclusion body myositis. Ann Clin Transl Neurol 2017;4:422-445.

7. Dalakas M. Molecular immunology and genetics of inflammatory muscle diseases. Arch Neurol 1998;55:1509-1512. 
8. Schmidt J, Barthel K, Wrede A, Salajegheh M, Bahr M, Dalakas MC. Interrelation of inflammation and APP in sIBM: IL-1 beta induces accumulation of beta-amyloid in skeletal muscle. Brain 2008;131(pt 5):1228-1240.

9. Schmidt J, Barthel K, Zschuntzsch J, et al. Nitric oxide stress in sporadic inclusion body myositis muscle fibres: inhibition of inducible nitric oxide synthase prevents interleukin-1beta-induced accumulation of beta-amyloid and cell death. Brain 2012; 135(pt 4):1102-1114.

10. Kosmidis ML, Alexopoulos H, Tzioufas AG, Dalakas MC. The effect of anakinra, an IL1 receptor antagonist, in patients with sporadic inclusion body myositis (sIBM): a small pilot study. J Neurol Sci 2013;334:123-125. 


\title{
Neurology \\ Neuroimmunology \& Neuroinflammation
}

\author{
Trial of canakinumab, an IL-1 $\beta$ receptor antagonist, in patients with inclusion body \\ myositis \\ Michalis L. Kosmidis, Dimitris Pikazis, Panayotis Vlachoyiannopoulos, et al. \\ Neurol Neuroimmunol Neuroinflamm 2019;6; \\ DOI 10.1212/NXI.0000000000000581
}

This information is current as of June 10, 2019

\section{Updated Information \& Services}

References

Subspecialty Collections

Permissions \& Licensing

Reprints including high resolution figures, can be found at:

http://nn.neurology.org/content/6/4/e581.full.html

This article cites 10 articles, 0 of which you can access for free at: http://nn.neurology.org/content/6/4/e581.full.html\#\#ref-list-1

This article, along with others on similar topics, appears in the following collection(s):

All Immunology

http://nn.neurology.org//cgi/collection/all_immunology

Class IV

http://nn.neurology.org//cgi/collection/class_iv

Clinical trials Observational study (Cohort, Case control)

http://nn.neurology.org//cgi/collection/clinical_trials_observational_stu dy_cohort_case_control

Muscle disease

http://nn.neurology.org//cgi/collection/muscle_disease

Information about reproducing this article in parts (figures,tables) or in its entirety can be found online at:

http://nn.neurology.org/misc/about.xhtml\#permissions

Information about ordering reprints can be found online:

http://nn.neurology.org/misc/addir.xhtml\#reprintsus

Neurol Neuroimmunol Neuroinflamm is an official journal of the American Academy of Neurology.

Published since April 2014, it is an open-access, online-only, continuous publication journal. Copyright

Copyright $\odot 2019$ The Author(s). Published by Wolters Kluwer Health, Inc. on behalf of the American

Academy of Neurology.. All rights reserved. Online ISSN: 2332-7812.

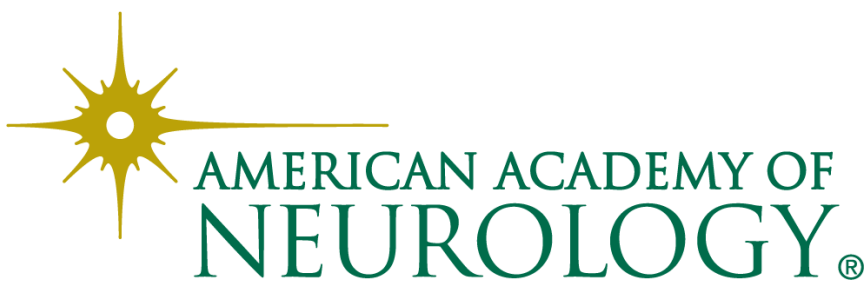

